\title{
KAJIAN PRASARANA PENDIDIKAN SEKOLAH DASAR SEBAGAI SALAH SATU INDIKATOR PENCAPAIAN STANDAR NASIONAL PENDIDIKAN
}

\section{STUDY OF PRIMARY SCHOOL INFRASTRUCTURE AS ONE OF INDICATOR IN ACHIEVING NATIONAL EDUCATION STANDARDS}

\author{
Relisa \\ Puslitjakdikbud, Balitbang Kemdikbud \\ Gedung E lantai 19, Jalan Jenderal Sudirman Senayan -Jakarta Pusat \\ Email: relisa@kemdikbud.go.id/miss.relisa@gmail.com
}

Naskah diterima tanggal: 25/02/2016, Direvisi akhir tanggal: 07/03/2016, disetujui tanggal: 25/03/2016

\begin{abstract}
This study aimed to study the level of achievement of primary school infrastructure standards in Banjarmasin City. This method of the research was intended to obtain data of the achievement of educational infrastructure. Results of the study showed that the level of achievement of primary school infrastructure reached $60,94 \%$. This level of achievement still seems to be low partly due to the lack of insfrastructure which is still owned by the school. In addition, although the school already has the infrastructure of education, the quality conditions of many infrastructures suffered heavy damage so it unfit for use. Types of infrastructure its educational echievement is higher than average includes: classroom, the boardroom, the teachers's room, and playground. On the contrary, the educational infrastructure is below average achievement including: school's health unit, library, and restroom. The conclusion of this study is that the achievement of educational infrastructure in Banjarmasin city has not met the requirements of education national standards.
\end{abstract}

Keywords: education infrastructure, primary school, education national standards

\begin{abstract}
Abstrak: Penelitian ini bertujuan untuk mengkaji tingkat ketercapaian standar prasarana pendidikan sekolah dasar di Kota Banjarmasin. Penelitian ini menggunakan metode survei. Hasil kajian menunjukkan bahwa tingkat ketercapaian prasarana pendidikan sekolah dasar mencapai 60,94\%. Tingkat ketercapaian yang tegolong rendah ini antara lain disebabkan oleh masih minimnya prasarana yang dimiliki sekolah. Di samping itu, kondisi kualitas prasarana banyak mengalami kerusakan berat sehingga tidak layak untuk digunakan. Jenisjenis prasarana pendidikan yang ketercapaiannya di atas rata-rata meliputi ruang kelas, ruang pimpinan, ruang guru, dan tempat bermain. Sebaliknya, prasarana pendidikan yang ketercapaiannya di bawah rata-rata meliputi ruang UKS, ruang perpustakaan, dan jamban(toilet). Penelitian ini menyimpulkan bahwa ketercapaian prasarana pendidikan di kota Banjarmasin belum memenuhi persyaratan standar nasional pendidikan.
\end{abstract}

Kata Kunci: prasarana pendidikan, sekolah dasar, standar nasional pendidikan

\section{PENDAHULUAN}

Dalam rangka tercapainya tujuan pembangunan nasional, pendidikan mempunyai peran yang sangat penting. Oleh karena itu, pemerintah akan terus meningkatkan pembangunan pendidikan yang bermutu. Berbagai kebijakan strategis untuk peningkatan mutu pendidikan telah ditetapkan pemerintah, salah satu di antaranya adalah Peraturan Pemerintah Nomor 19, Tahun 2005 tentang Standar Nasional Pendidikan (SNP) (PP No. 19 Tahun 2005). SNP merupakan acuan dalam rangka mengembangkan mutu pendidikan dan telah dijabarkan menjadi delapan standar, yaitu 1) Standar Isi; 
2) Standar Kompetensi Lulusan; 3) Standar Kompetensi Pendidik dan Tenaga Kependidikan; 4) Standar Proses; 5) Standar Pengelolaan; 6) Standar Sarana Prasarana; 7) Standar Pembiayaan; dan 8) Standar Penilaian.

Ditetapkannya PP No. 19 Tahun 2005 juga merupakan penjabaran tindak lanjut dari Undang-Undang Nomor 20 Tahun 2003 tentang Sistem Pendidikan Nasional (UU 20/2003) yang dilatarbelakangi adanya kenyataan bahwa mutu pendidikan di Indonesia masih rendah. Hal ini antara lain didukung oleh data dari United Nation Development Programme (UNDP) tentang peringkat Indeks Pembangunan Manusia (Human Development Index/HDI) yang mencakup pembangunan pendidikan, kesehatan, dan penghasilan per kapita yang menunjukkan penurunan. Posisi HDI Indonesia di antara 174 negara di dunia pada tahun 1996 sampai dengan tahun 1999 dan tahun 2014 menduduki urutan ke-102, ke-99, ke-105, ke-109, dan urutan ke108 (http://unic-jakarta.org/2014/07/25/). Mutu pendidikan di Indonesia yang rendah dapat dilihat juga dari data Balitbang, Depdiknas (2003) bahwa dari 146.052 SD hanya ada 8 SD yang mendapat pengakuan dunia dalam kategori The Primary Year Program, dari 20.918 SMP hanya ada 8 SMP yang mendapat pengakuan dunia dalam kategori The Middle Year Program, dan dari 8.036 SMA hanya 7 SMA yang mendapat pengakuan dunia dalam kategori The Diploma Program (https://uses.wordpress.com/ kualitas-pendidikan-di-indonesia/).

Rendahnya mutu tersebut dipengaruhi oleh berbagai faktor yang berhubungan dengan sistem pendidikan. Oleh karena itu, ditetapkannya SNP dimaksudkan agar mutu pendidikan di Indonesia dapat tercapai secara merata di seluruh wilayah hukum Negara Kesatuan Republik Indonesia (NKRI). Lebih lanjut, SNP yang ditetapkan berfungsi sebagai dasar dalam perencanaan, pelaksanaan, dan pengawasan pendidikan dalam rangka mewujudkan pendidikan nasional yang bermutu. Dengan demikian, upaya peningkatan mutu pendidikan harus dilakukan secara terpadu antara penyelenggara dan pembina pendidikan di semua jenis, jenjang, dan satuan pendidikan. Perbaikan dan peningkatan mutu pendidikan merupakan komitmen nasional yang menjadi tanggung jawab bersama antara pemerintah pusat, pemerintah daerah, masyarakat, dan dunia usaha/industri (DU/DI).

Setelah PP 19/2005 diimplementasikan, ternyata belum memberikan hasil yang maksimal terhadap peningkatan mutu pendidikan. Berbagai kondisi menunjukkan bahwa mutu pendidikan masih belum meningkat secara signifikan. Indeks pembangunan pendidikan untuk semua education for all development index (EDI) di Indonesia menurun (Kompas.com, 2011). Jika pada tahun 2010 Indonesia berada di peringkat 65, pada tahun 2011 menurun ke peringkat 69, dan pada tahun 2012 turun berada di peringkat 68 (UNESCO, 2015). Hal ini juga dinyatakan dalam Education For All (EFA) Global Monitoring Report (2011) The Hidden Crisis, Armed Conflict and Education yang dikeluarkan Organisasi Pendidikan, Ilmu Pengetahuan, dan Kebudayaan Perserikatan Bangsa-Bangsa (UNESCO, 2011) bahwa EDI berdasarkan data tahun 2008 adalah 0,934. Nilai tersebut menempatkan Indonesia pada posisi ke-69 dari 127 negara di dunia. Kategori EDI dikatakan tinggi jika mencapai 0,95 s.d. 1 dan kategori medium berada di antara 0,80 s.d. 0,95, sedangkan kategori rendah berada di bawah 0,80 . Faktor yang menentukan mutu pendidikan adalah guru, di mana kualitas guru belum sesuai dengan standar yang diinginkan. Hal itu ditunjukkan adanya nilai rata-rata hasil $\mathrm{Uji}$ Kompetensi Guru (UKG) masih rendah (Kompas.com, 2012). Di samping itu, kondisi tersebut diungkapkan Menteri Pendidikan dan Kebudayaan bahwa "dari hasil pemindaian yang baru berjalan $82 \%$, diperoleh nilai rata-rata guru SD mencapai angka 35 dari 100 soal yang dikerjakan, dan guru IPA/IPS nilai rata-rata hanya mencapai 46. Memperhatikan data tersebut dapat diperkirakan bahwa masih banyak aspek mutu pendidikan di Indonesia yang belum meningkat secara signifikan walaupun SNP telah diimplementasikan sejak tahun 2005. 
Keberadaan SNP diharapkan dapat menjamin mutu pendidikan di Indonesia dalam arti yang luas, yaitu mencerdaskan kehidupan bangsa dan membentuk watak serta peradaban bangsa yang bermartabat. Namun, adanya standar pendidikan sering juga menghambat peningkatan mutu karena adanya potensi negatif yang tersembunyi, yaitu adanya pendidikan yang terkungkung hanya karena ketentuan standar sehingga kehilangan makna terhadap tujuan pendidikan yang akan dicapai. Oleh karena itu, pada ketentuan SNP dinyatakan juga bahwa SNP perlu disempurnakan secara terencana, terarah, dan berkelanjutan sesuai dengan tuntutan perubahan kehidupan lokal, nasional, dan global.

Salah satu SNP yang penting dalam upaya peningkatan mutu pendidikan adalah standar sarana dan prasarana. Layanan sarana dan prasarana bertujuan untuk memenuhi standar nasional yang ditetapkan (Triwiyanto, 2013). Standar sarana dan prasarana merupakan standar minimal yang harus dipenuhi oleh setiap satuan pendidikan. Standar dimaksud meliputi gedung (ruang belajar), lahan, perpustakaan, dan prasarana lainnya yang digunakan dalam pembelajaran. Dalam kenyataannya, pemenuhan standar sarana dan prasarana itu belum maksimal. Dari berbagai informasi yang diperoleh dinyatakan, bahwa masih banyak gedung sekolah yang tidak layak untuk pembelajaran. Sekolah masih banyak yang belum mempunyai perpustakaan dan prasarana belajar lainnya. Hasil penelitian BAN S/M menunjukkan bahwa terdapat jumlah satuan pendidikan yang cukup besar tidak memenuhi SNP, sehingga memerlukan dukungan dana dari pemerintah agar dapat memenuhi SNP. Komponen SNP yang belum sepenuhnya dapat dipenuhi terkait dengan standar kompetensi lulusan, standar pendidik dan kependidikan, serta standar sarana prasarana (Subijanto \& Wiratno, 2012). Hasil penelitian yang lain juga memperkuat bahwa standar sarana prasarana merupakan standar yang pemenuhannya masih kurang. Dari delapan standar yang ada, standar yang masih rendah adalah standar sarana prasarana, standar proses, standar kompetensi, dan standar tenaga pendidik dan kependidikan (Raharjo, 2014).

Dalam Rembug Nasional Kementerian Pendidikan dan Kebudayaan (Kementerian Pendidikan dan Kebudayaan, 2012), salah satu program yang menjadi fokus adalah penuntasan rehabilitasi ruang kelas rusak dan peningkatan sarana prasarana di daerah terpencil, tertinggal, terdepan/terluar (3T), perbatasan, dan klaster 4. Jumlah sekolah yang rusak pada jenjang pendidikan dasar seperti yang tertera pada Tabel 1.

Dalam upaya memenuhi ketercapaian standar sarana prasarana khususnya bidang pendidikan dasar, pemerintah telah memberikan bantuan sarana prasarana dalam berbagai bentuk bantuan antara lain melalui dana alokasi khusus (DAK) dan bantuan sosial (bansos). Pada kenyataannya upaya tersebut masih belum memenuhi kebutuhan sarana prasarana di sekolah secara menyeluruh. Hal ini disebabkan antara lain oleh distribusi bantuan yang belum tepat sasaran. Banyak sekolah yang menerima bantuan sarana prasarana, namun bantuan dimaksud sebenarnya tidak dibutuhkan. Sebaliknya, banyak sekolah yang membutuhkan sarana prasarana akan tetapi belum mendapatkan bantuan. Melalui berbagai program bantuan sarana prasarana yang telah diberikan

Tabel 1 Jumlah sekolah yang rusak

\begin{tabular}{lllllll}
\hline \multirow{2}{*}{ Jenjang } & \multicolumn{2}{c}{ Kebutuhan } & \multicolumn{2}{c}{ Rehabilitasi 2011 } & \multicolumn{2}{c}{ Rencana Rehabilitasi 2012 } \\
& \multicolumn{1}{c}{ Ruang } & Anggaran & Ruang Kelas & \multicolumn{1}{c}{ Anggaran } & Ruang Kelas & \multicolumn{1}{c}{ Anggaran } \\
\hline SD & 150.317 & 14.338 .564 & 18.000 & 2.297 .671 & 132.317 & 12.040 .893 \\
SMP & 44.527 & 4.299 .770 & 3.500 & 518.420 & 41.027 & 3.781 .350 \\
TOTAL & 194.844 & 18.638 .334 & 21.500 & 2.816 .090 & 173.344 & 15.822 .243 \\
\hline
\end{tabular}

Sumber: Bahan Rembugnas Kemendikbud, 2012 
oleh pemerintah kepada sekolah diharapkan kebutuhan sarana prasarana tersebut dapat terpenuhi untuk menunjang penyelenggaraan kegiatan pembelajaran dan meningkatkan mutu pendidikan. Namun, hingga saat ini jumlah bantuan tersebut dirasakan belum mencukupi dari segi kuantitas dan pendistribusiannya belum merata. Hal ini mengakibatkan masih terjadi kesenjangan antara kebutuhan sarana dan prasarana sekolah dan bantuan yang diberikan serta kesenjangan antarsekolah.

Kelebihan keberadaan dan penggunaan sarana dan prasarana dalam meningkatkan mutu pembelajaran antara lain: a) memudahkan guru dalam menyampaikan materi pembelajaran; b) memudahkan peserta didik menerima/memahami materi; c) memudahkan dalam mengakses informasi pendidikan; d) meningkatkan minat baca peserta didik; e) menanamkan jiwa anti korupsi sejak dini; f) memudahkan dalam ulangan; g) membantu pengembangan bakat peserta didik; h) memudahkan pemahaman teori/ konsep melalui praktikum; i) mengembangkan psikomotorik peserta didik; j) mendukung lingkungan kelas (dalam dan luar) menjadi bersih; k) suasana kelas yang selalu kondusif dan nyaman (Jannah, 2010). Selanjutnya, dinyatakan bahwa kekurangan pengelolaan sarana dan prasarana, antara lain meliputi a) pemeliharaan sarana dan prasarana kurang efektif; b) penanggung jawab dan petugas sarana prasarana terbatas dan kurang efektif; c) jadwal penggunaan laboratorium sering berbenturan, d) petunjuk penggunaan media sering tidak diperhatikan (diabaikan) oleh peserta didik; dan e) sarana dan prasarana kurang terawat dengan baik (Jannah, 2010).

Kondisi tersebut didukung oleh Santosa (2011) bahwa terdapat hubungan yang signifikan antara variabel pengelolaan sarana prasarana sekolah dengan motivasi berprestasi guru. Semakin baik pengelolaan sarana dan prasarana sekolah, motivasi guru berprestasi akan semakin meningkat. Berkaitan dengan hal tersebut, perlu diketahui seberapa jauh SNP yang berkaitan dengan sarana dan prasarana telah dipenuhi oleh setiap satuan pendidikan.

Dari uraian tersebut, rumusan permasalahan terkait dengan penelitian ini adalah bagaimana tingkat ketercapaian standar sarana prasarana khususnya prasarana pada jenjang sekolah dasar di Kota Banjarmasin? Mengacu pada masalah, tujuan penelitian ini adalah mengkaji tingkat ketercapaian standar sarana prasarana pendidikan pada jenjang sekolah dasar khususnya di Kota Banjarmasin.

\section{KAJIAN LITERATUR}

\section{Standar Nasional Pendidikan (SNP)}

SNP merupakan kriteria minimal tentang sistem pendidikan yang diberlakukan di seluruh wilayah hukum Negara Kesatuan Republik Indonesia (NKRI). SNP berfungsi sebagai dasar dalam perencanaan, pelaksanaan, dan pengawasan pendidikan dalam rangka mewujudkan pendidikan nasional yang bermutu. Di sisi lain, SNP bertujuan untuk menjamin mutu pendidikan nasional dalam rangka mencerdaskan kehidupan bangsa dan membentuk watak serta peradaban bangsa yang bermartabat.

Sebagaimana tersurat dan tersirat dalam UU No. 20 Tahun 2003, secara yuridis Indonesia telah menerapkan paradigma pendidikan berbasis standar dalam sistem pendidikan nasional. Secara konkrit, PP No. 19 Tahun 2005 merupakan bukti nyata penerapan atau penggunaan paradigma pendidikan berbasis standar dalam sistem pendidikan nasional di Indonesia. Sebagaimana tercantum dalam UU No. 20 Tahun 2003 dan PP No. 19 Tahun 2005, terdapat delapan standar nasional pendidikan di Indonesia sebagai acuan secara nasional dalam upaya meningkatkan mutu pendidikan. Hasil penelitian (Raharjo, 2012) yang menyatakan bahwa setiap satuan pendidikan memberi tanggapan yang positif dan menerapkan standar nasional pendidikan secara optimal. Hal ini didukung oleh adanya data yang menunjukkan kualitas dan persentase lulusan cenderung naik, walaupun jumlah sekolah yang terakreditasi 
pada umumnya hanya mencapai nilai $B$ dengan tingkat pemenuhan delapan standar nasional mencapai 73,55\% untuk SD, 85,97\% untuk SMP, $77,07 \%$ untuk SMA, dan 76,15\% untuk SMK.

Dalam hal pengelolaan sarana prasana beberapa tahapan yang dilakukan meliputi 1 ) perencanaan dan pengadaan sarana prasarana; 2) pendistribusian sarana dan prasarana, 3) penggunaan dan pemeliharaan sarana prasarana, serta 4) inventaris sarana prasarana (Dharmastuti, 2014). Perencanaan dan pengadaan memiliki peran yang penting dalam mencapai tujuan dari penggunaan sarana prasarana.

\section{Ketercapaian Standar Sarana dan Prasarana}

Pengertian sarana dan prasarana secara etimologi dapat diuraikan seperti berikut ini. Sarana dimaknai sebagai alat untuk mencapai tujuan pendidikan. Menurut Kamus Besar Bahasa Indonesia daring (2008), sarana adalah segala sesuatu yang dipakai sebagai alat untuk mencapai makna dan tujuan. Selanjutnya, prasarana berarti alat tidak langsung untuk mencapai tujuan dalam pendidikan, misalnya lokasi/tempat, bangunan sekolah, dan lapangan olahraga. Menurut Kamus Besar Bahasa Indonesia Daring (2008) prasarana adalah segala sesuatu yang merupakan penunjang utama terselenggaranya suatu proses. Oleh karena itu, prasarana pendidikan adalah segala macam alat, perlengkapan, atau benda-benda yang dapat digunakan untuk memudahkan (membuat nyaman) dalam pelaksanaan pendidikan.

Inventaris sarana prasarana memiliki keterkaitan pada pemenuhan sarana prasarana pendidikan di sekolah. Permasalahan pembiayaan dalam pemenuhan sarana prasana tidak hanya peran kepala sekolah yang menjadi tombak utama dalam pemenuhan tersebut. Beberapa upaya yang dapat dilakukan dalam mengatasi masalah tersebut yaitu dengan mengajukan permohonan kepada pemerintah, bantuan orangtua siswa, dan bantuan masyarakat yang peduli pendidikan sehingga pemenuhan sarana prasarana pendidikan di sekolah tercapai.

\section{Kriteria Umum Standar Sarana Prasarana}

SNP di Indonesia terdiri atas delapan standar pendidikan. Salah satu standar tersebut adalah Sarana dan Prasarana. Standar Sarana dan Prasarana ditetapkan dalam Peraturan Menteri Pendidikan Nasional Republik Indonesia Nomor 24, Tahun 2007 tentang Standar Sarana dan Prasarana untuk Sekolah Dasar/Madrasah Ibtidaiyah (SD/MI), Sekolah Menengah Pertama/ Madrasah Tsanawiyah (SMP/MTs), dan Sekolah Menengah Atas/Madrasah Aliyah (SMA/MA) (Peraturan Menteri Pendidikan Nasional,2007). Standar sarana dan prasarana adalah standar nasional pendidikan yang berkaitan dengan kriteria minimal tentang ruang belajar, tempat olahraga, tempat ibadah, perpustakaan, laboratorium, bengkel kerja, tempat bermain, tempat berkreasi dan berekreasi, serta sumber belajar lain yang diperlukan untuk menunjang proses pembelajaran, termasuk penggunaan teknologi informasi dan komunikasi (Peraturan Menteri Pendidikan Nasional,2007).

Menurut Herlino (2013) pengelolaan sarana dan prasarana pendidikan di sekolah meliputi analisis dan penyusunan kebutuhan, pengadaan, penyaluran, pemakaian dan pemeliharaan inventaris, dan penghapusan. Sarana pendidikan merupakan perlengkapan yang diperlukan untuk menyelenggarakan pembelajaran yang dapat dipindah-pindah dan prasarana pendidikan adalah fasilitas dasar yang diperlukan untuk menjalankan fungsi satuan pendidikan. PP No. 19 Tahun 2005 yang menyangkut standar sarana dan prasarana pendidikan secara nasional tertuang pada Bab VII Pasal 42 dengan tegas disebutkan bahwa (1) Setiap satuan pendidikan wajib memiliki sarana yang meliputi perabot, peralatan pendidikan, media pendidikan, buku dan sumber belajar lainnya, bahan habis pakai, serta perlengkapan lain yang diperlukan untuk menunjang proses pembelajaran yang teratur dan berkelanjutan; (2) Setiap satuan pendidikan wajib memiliki prasarana yang meliputi lahan, 
ruang kelas, ruang pimpinan satuan pendidikan, ruang pendidik, ruang tata usaha, ruang perpustakaan, ruang laboratorium, ruang bengkel kerja, ruang unit produksi, ruang kantin, instalasi daya dan jasa, tempat berolahraga, tempat beribadah, tempat bermain, tempat berkreasi, dan ruang/tempat lain yang diperlukan untuk menunjang proses pembelajaran yang teratur dan berkelanjutan.

Pelaksanaan pendidikan nasional harus menjamin pemerataan dan peningkatan mutu pendidikan di tengah perubahan global agar warga Indonesia menjadi manusia yang bertakwa kepada Tuhan Yang Maha Esa, berakhlak mulia, cerdas, produktif, dan berdaya saing tinggi dalam pergaulan nasional maupun internasional. Untuk menjamin tercapainya tujuan pendidikan tersebut, pemerintah telah mengamanatkan penyusunan delapan standar nasional pendidikan sebagaimana diatur dalam PP No. 19 Tahun 2005. Standar nasional pendidikan adalah kriteria minimum tentang sistem pendidikan di seluruh wilayah hukum NKRI. Pelaksanaan pembelajaran dalam pendidikan nasional berpusat pada peserta didik agar dapat a) belajar untuk beriman dan bertakwa kepada Tuhan Yang Maha Esa; b) belajar untuk memahami dan menghayati; c) belajar untuk mampu melaksanakan dan berbuat secara efektif; d) belajar untuk hidup bersama dan berguna bagi orang lain; dan e) belajar untuk membangun dan menemukan jati diri melalui proses belajar yang aktif, kreatif, efektif, dan menyenangkan. Hal ini selaras dengan hasil penelitian (Basuki, 2010) yang menyatakan bahwa terdapat: 1) pengaruh positif dan signifikan antara pemanfaatan alat pelajaran terhadap motivasi belajar siswa; 2) pengaruh yang positif dan signifikan antara pemanfaatan alat peraga terhadap motivasi belajar siswa; 3) pengaruh yang positif dan signifikan antara pemanfaatan media pengajaran terhadap motivasi belajar siswa; dan 4) pengaruh yang positif dan signifikan antara bangunan sekolah terhadap motivasi belajar siswa.
Untuk menjamin terwujudnya hal tersebut diperlukan adanya sarana dan prasarana yang memadai. Sarana dan prasarana yang memadai tersebut harus memenuhi ketentuan minimum yang ditetapkan dalam standar sarana dan prasarana. Standar sarana dan prasarana ini berlaku untuk lingkup pendidikan formal, jenis pendidikan umum, jenjang pendidikan dasar dan menengah yaitusekolah dasar/madrasah ibtidaiyah (SD/MI), sekolah menengah pertama/ madrasah tsanawiyah (SMP/MTs), dan sekolah menengah atas/madrasah aliyah (SMA/MA).

\section{Prasarana Pendidikan}

Menurut Permendiknas No. 24 Tahun 2007, prasarana merupakan fasilitas dasar untuk menjalankan fungsi sekolah/madrasah. Fasilitas dasar tersebut terdiri atas ruang kelas, ruang perpustakaan, ruang laboratorium IPA, ruang pimpinan, ruang guru, tempat beribadah, ruang UKS, jamban (toilet), gudang, ruang sirkulasi, tempat bermain/berolahraga. Menurut Dimyati dan Mudjiono (2006) prasarana pembelajaran meliputi gedung sekolah, ruang belajar, lapangan olahraga, ruang ibadah, ruang kesenian, dan peralatan olahraga. Sarana pembelajaran meliputi buku pelajaran, buku bacaan, alat, fasilitas olahraga, dan berbagai media pembelajaran lainnya.

Beberapa prasarana pendidikan dapat dikategorikan berdasarkan fungsinya menjadi dua jenis, yaitu prasarana langsung dan tidak langsung dalam menunjang pembelajaran. Untuk kategori prasarana langsung adalah prasarana yang dapat langsung digunakan dalam menunjang pembelajaran, seperti ruang kelas, ruang perpustakaan, dan ruang laboratorium. Sedangkan untuk kategori prasarana tidak langsung digunakan dalam proses pembelajaran seperti kantin, kamar kecil, ruang pimpinan, dan ruang guru.

Selain fungsinya yang menjadi keutamaan pada sebuah ruang, kelengkapan perabot dan peralatan juga memiliki peran penting dalam menunjang fungsi ruang tersebut. Kriteria 
minimum prasarana terdiri atas lahan, bangunan, ruang-ruang, dan instalasi daya dan jasa yang wajib dimiliki oleh setiap sekolah. Pada setiap ruang, memiliki arti sesuai dengan fungsinya seperti 1) ruang kelas merupakan ruang untuk pembelajaran teori dan praktiek yang tidak memerlukan peralatan khusus; 2) ruang perpustakaan merupakan ruang untuk menyimpan dan memperoleh informasi dari berbagai jenis bahan pustaka; 3) ruang laboratorium merupakan ruang untuk pembelajaran secara praktik yang memerlukan peralatan khusus; 4) ruang pimpinan merupakan ruang untuk pimpinan melakukan kegiatan pengelolaan sekolah; 5) ruang guru merupakan ruang untuk guru bekerja di luar kelas, beristirahat, dan menerima tamu; 6) ruang konseling merupakan ruang untuk peserta didik mendapatkan layanan konseling dari konselor berkaitan dengan pengembangan pribadi, sosial, belajar,dan karir.

\section{METODE}

Penelitian ini menggunakan metode survei dan populasi penelitian adalah semua sekolah dasar di Kota Banjarmasin. Sampel disusun secara purposif sehingga ditemukan 12 sekolah dasar di Kota Banjarmasin. Kegiatan survei ditujukan untuk memperoleh data tentang ketercapaian sarana dan prasarana. Teknik pengumpulan data menggunakan kuesioner dan wawancara (Sugiyono, 2011). Penelitian ini dilakukan pada tahun 2012, dengan lingkup penelitian meliputi prasarana utama yang ada di sekolah dasar regular sebanyak tujuh jenis, yaitu ruang kelas, ruang pimpinan, ruang perpustakaan, ruang guru, ruang UKS, jamban (toilet), tempat bermain dan olahraga. Sebagai responden dari penelitian ini adalah kepala sekolah/staf pengelola sarana prasarana sekolah. Teknik analisis data yang dilakukan dalam kajian ini adalah secara deskriptif, seperti menghitung frekuensi untuk mengetahui ketercapaian sarana dan prasarana di sekolah sampel.

\section{HASIL DAN PEMBAHASAN Ketercapaian Prasarana Pendidikan}

Ketercapaian standar sarana dan prasarana pendidikan dapat diperoleh dengan membandingkan ketentuan standar sarana dan prasarana dengan kondisi tersedia pada satuan pendidikan baik kuantitas, kualitas, maupun spesifikasi sarana tersebut sesuai dengan peruntukannya. Kesesuaian antara ketentuan standar dengan kondisi nyata di lapangan merupakan ketercapaian standar yang dinyatakan dengan persentase (\%). Persentase tersebut menggambarkan tingkat ketercapaian standar sarana dan prasarana pendidikan di satuan pendidikan. Dalam kajian ini, yang menjadi fokus adalah prasarana dan jumlah perabot yang tertera dalamnya.

Menurut Permendiknas No. 24 Tahun 2007, prasarana adalah fasilitas dasar untuk menjalankan fungsi sekolah. Prasarana terdiri atas tiga jenis, yaitu perabot, peralatan pendidikan, dan media pendidikan. Setiap jenis prasarana terdiri atas tiga unsur bahkan lebih. Berikut uraian temuan dan pembahasan ketercapaian prasarana sekolah di Kota Banjarmasin.

\section{Ruang Kelas}

Ruang kelas merupakan sarana utama dalam proses pembelajaran. Berdasarkan standar sarana prasana, ruang kelas terdiri atas beberapa unsur/bagian. Jenis prasarana pada ruang kelas terdiri atas perabot, peralatan pendidikan, dan perlengkapan lain. Pada perabot capaian terendah dari segi kepemilikan adalah, lemari $(38,6 \%)$ dan terbesar adalah meja guru $(79,5 \%)$ dibandingkan dengan jenis perabot lain yang ada di ruang kelas. Secara fungsi, lemari bukan sebagai perabot utama yang diperlukan dalam menunjang proses pembelajaran. Pada beberapa sekolah, keberadaan lemari di kelas tidak ditemukan. Beberapa sekolah mengatakan bahwa fungsi lemari di dalam kelas dibedakan menjadi dua. Sekolah yang tidak memiliki ruang laboratorium menjadikan lemari di kelas untuk penyimpanan alat-alat laboratorium. Namun, 
sebagian sekolah mengatakan bahwa lemari yang ada di kelas telah dipindahkan untuk keperluan guru. Pada unsur peralatan pendidikan dan perlengkapan lainnya masih rendah, ketercapaian kepemilikan alat peraga $(31,4 \%)$ dan tempat cuci tangan $(35,7 \%)$. Beberapa sekolah di kota Banjarmasin sudah banyak yang memiliki ruang laboratorium IPA. Hal yang sama dengan tempat cuci tangan di kelas, penempatannya tidak di dalam kelas melainkan di luar kelas atau di toilet.

Secara keseluruhan perabot, peralatan, dan perlengkapan lain pada ruang kelas, ketercapaian ruang kelas adalah $62,83 \%$ artinya belum maksimal. Hal ini dikarenakan ketepatan perabotan dan perlengkapan lainnya sudah tidak sesuai dengan kebutuhan proses pembelajaran pada saat ini. Data secara terinci terlampir pada Tabel 2.

Tabel 2 Ketercapaian Ruang Kelas (\%)

\begin{tabular}{lc}
\hline \multicolumn{1}{c}{ Jenis Prasarana } & $\begin{array}{c}\text { Persentase } \\
\text { ketercapaian }\end{array}$ \\
\hline Perabot & $38,6 \%$ \\
Lemari & $54,5 \%$ \\
Papan pajang & $72,7 \%$ \\
Kursi peserta didik & $75,0 \%$ \\
Kursi guru & $75,0 \%$ \\
Meja peserta didik & $79,5 \%$ \\
Meja guru & \\
Peralatan Pendidikan & $31,4 \%$ \\
Alat peraga & \\
Perlengkapan Lain & $35,7 \%$ \\
Tempat cuci tangan & $61,9 \%$ \\
Tempat sampah & $72,1 \%$ \\
Jam dinding & $72,1 \%$ \\
Stop kontak & $85,4 \%$ \\
Papan tulis & \\
\hline
\end{tabular}

Sumber: Data diolah tahun 2014Instrumen Ketercpaian Standar Nasional Pendidikan Tahun 2012

\section{Ruang Pimpinan}

Ruang pimpinan merupakan salah satu faktor pendukung kelancaran dalam manajemen sekolah. Ruang pimpinan berfungsi sebagai tempat melakukan kegiatan pengelolaan sekolah, pertemuan dengan sejumlah guru, dan orang tua siswa. Selain itu, ruang pimpinan harus mudah diakses oleh guru, siswa, dan tamu.

Pada umumnya, kepemilikan prasarana yang ada di ruang pimpinan sudah tersedia, hal ini dinyatakan dengan hampir 50 persen kepemilikan prasarana yang terdiri atas perabot dan perlengkapan lain. Pada perabot, kepemilikan papan statistik $(60,5 \%)$ lebih rendah jika dibandingkan dengan perabot yang lain. Hal ini dikarenakan papan statistik yang memiliki fungsi kurang mendukung pembelajaran dikarenakan hanya berisikan data kepegawaian. Pada beberapa sekolah sampel, kuantitas papan statistik tidak menginformasikan kondisi yang aktual, banyak data kepegawaian yang sudah tidak sesuai dengan kondisi sekolah, misalnya guru/pegawai sudah pindah atau sudah meninggal. Kinerja kepala sekolah terbantu dalam ketersediaan kursi pimpinan dan meja pimpinan. Pada perabot tersebut ketercapaian kepemilikian di tiap sekolah sampel tinggi di atas $50 \%$. Selain itu, kepemilikan lemari $(90,9 \%)$ di ruang pimpinan pada sekolah sampel juga tinggi, artinya secara kebutuhan keberadaan lemari sangat mendukung kelengkapan dalam membantu kinerja kepala sekolah, dengan tersusunnya dokumen-dokumen penting secara rapi di dalam lemari. Untuk mendukung kelancaran dalam proses manajemen sekolah, ketersediaan kursi dan meja tamu juga memiliki andil. Hal ini terbukti pada tingkat ketercapaian kepemilikan kursi dan meja tamu $(93,0 \%)$ di ruang kepala sekolah. Untuk tempat cuci tangan, hanya beberapa sekolah sampel yang menyediakan secara terpisah dengan kamar mandi. Keberadaan tempat cuci tangan di beberapa sekolah lain dilakukan di kamar mandi kepala sekolah/guru. Secara keseluruhan, tingkat ketercapaian pada ruang pimpinan sudah memenuhi standard dari segi perabotdan perlengkapan lain. Rincian data terlampir pada Tabel 3. Secara keseluruhan ketercapaian pada ruang pimpinan dari segi kepemilikan yaitu 7.84 persen. 
Tabel 3 Ketercapaian Ruang Pimpinan (\%)

\begin{tabular}{lc}
\hline \multicolumn{1}{c}{ Jenis prasarana } & $\begin{array}{c}\text { Persentase } \\
\text { ketercapaian }\end{array}$ \\
\hline Perabot & \\
Papan statistik & $60,5 \%$ \\
Lemari & $90,9 \%$ \\
Kursi dan meja tamu & $93,0 \%$ \\
Kursi pimpinan & $93,2 \%$ \\
Meja pimpinan & $95,5 \%$ \\
Perlengkapan Lain & \\
Tempat cuci tangan & $32,6 \%$ \\
Tempat sampah & $79,5 \%$ \\
Simbol kenegaraan & $84,1 \%$ \\
Jam dinding & $86,0 \%$ \\
\hline
\end{tabular}

Sumber: Data diolah tahun 2014

Instrumen Ketercapaian Standar Nasional Pendidikan Tahun 2012

\section{Ruang Perpustakaan}

Ruang perpustakaan merupakan ruangan untuk menyimpan dan memperoleh informasi dari berbagai jenis bahan perpustakaan. Secara fungsinya, ruang perpustakaan berfungsi sebagai tempat kegiatan guru dan siswa memperoleh informasi dari berbagai jenis bahan pustaka dengan membaca, mengamati, mendengar, dan sekaligus tempat petugas mengelola perpustakaan. Dari definisi dan fungsi dari perpustakaan, maka perpustakaan harus memiliki beberapa jenis sarana seperti jenis buku yang dimiliki, perabot, media pendidikan, dan media lain dengan kondisi yang sesuai dengan standar dan baik untuk menunjang keberhasilan dalam proses pembelajaran. Kepemilikan pada keempat komponen tersebut dirinci seperti berikut ini.

Buku merupakan salah satu hal utama yang harus ada dalam perpustakaan. Jumlah dan variasi judul buku yang banyak dan beragam menggambarkan kualitas dan fungsi perpustakaan yang baik. Jenis buku yang ada di perpustakaan terdiri dari buku teks, buku panduan pendidik, buku pengayaan, buku referensi, dan buku lainnya. Pada sekolah sampel yang diteliti, kepemilikan jenis buku masih sangat rendah dilihat dari persentase kepemilikan buku belum mencapai $100 \%$. Buku teks merupakan buku pegangan yang dimiliki oleh siswa sesuai dengan kurikulum yang digunakan. Buku teks sebagai pegangan siswa di sekolah maupun di rumah, dalam hal ini kepemilikannya mencapai $68,20 \%$. Hal ini dapat diartikan bahwa belum semua siswa memiliki buku teks, sedangkan dalam standar kepemilikan setiap peserta didik memiliki satu eksemplar buku teks per mata pelajaran ditambah dua eksemplar per mata pelajaran pada setiap sekolah. Buku panduan merupakan buku pegangan untuk guru, dari tingkat kepemilikan buku panduan menunjukkan yang paling rendah, yaitu 22,70\%. Hal ini berarti bahwa belum semua guru memiliki buku panduan satu buku per mata pelajaran. Masih sangat jauh dengan standar yang menetapkan bahwa rasio kepemilikan buku panduan satu eksemplar per mata pelajaran pada setiap guru. Buku pengayaan dan buku referensi merupakan buku yang digunakan oleh guru sebagai buku penunjang dan referensi dalam meningkatkan dan memperluas informasi dan pengetahuan siswa.

Perabot pada perpustakaan terdiri dari beberapa barang yang menunjang kegiatan di perpustakaan. Jenis perabot terdiri dari rak buku, rak majalah, rak surat kabar, meja baca, kursi baca, kursi kerja, meja kerja, lemari katalog, lemari, papan pengumuman, dan meja multimedia. Secara keseluruhan ketercapaian pada ruang perpustakaan adalah 56.94\%. Data terlampir pada Tabel 4.

\section{Ruang Guru}

Ruang guru berfungsi sebagai tempat guru bekerja,istirahat serta menerima tamu. Ruang guru merupakan salah satu prasarana yang mendukung dari kegiatan guru setelah melakukan proses belajar mengajar. Menurut standar sarana prasana jenis prasarana di ruang guru terdiri dari kursi dan meja tamu, papan statistik, kursi kerja, meja kerja, lemari, dan papan pengumuman, sedangkan pada perlengkapan lain terdiri dari tempat sampah, tempat cuci tangan, dan jam dinding. 
Tabel 4 Ketercapaian Ruang Perpustakaan $(\%)$

\begin{tabular}{lc}
\hline \multicolumn{1}{c}{ Jenis sarana } & $\begin{array}{r}\text { Persentase } \\
\text { Ketercapaian }\end{array}$ \\
\hline Buku & \\
Buku teks & $68,20 \%$ \\
Buku panduanpendidik & $22,70 \%$ \\
Buku engayaan & $50,00 \%$ \\
Buku referensi & $63,60 \%$ \\
Sumber lainnya & $40,90 \%$ \\
Perabot & \\
Rak buku & $86,40 \%$ \\
Rak majalah & $52,30 \%$ \\
Rak suratkabar & $56,80 \%$ \\
Mejabaca & $22,70 \%$ \\
Kursi baca & $27,30 \%$ \\
Kursi kerja & $84,10 \%$ \\
Meja kerja & $72,70 \%$ \\
Lemari katalog & $56,80 \%$ \\
Lemari & $72,70 \%$ \\
Papan pengumuman & $56,80 \%$ \\
Meja multimedia & $34,10 \%$ \\
Media pendidikan & \\
Peralatan multimedia & $43,20 \%$ \\
Perlengkapan lain & \\
Buku inventaris & $81,80 \%$ \\
Tempat sampah & $72,70 \%$ \\
Stop kontak & $65,90 \%$ \\
Jam dinding & $63,60 \%$ \\
\hline
\end{tabular}

Sumber: Data diolah tahun 2014 Instrumen Ketercapaian Standar Nasional Pendidikan Tahun 2012

Dari rincian jenis prasarana yang dimiliki di ruang guru, yaitu kursi dan meja tamu ketercapaiannya rendah $(38,6 \%)$. Hal ini dikarenakan keterbatasan lahan yang dimiliki oleh beberapa sekolah. Penerimaan tamu untuk guru biasanya dilakukan di ruang tamu yang berdekatan dengan kepala sekolah.

Papan statistik guru dan pegawai merupakan data guru dan pegawai yang tertera dipajang dalam ruang guru. Ketercapaian dalam hal kepemilikan $(59,1 \%)$ hampir seluruh sekolah memiliki papan statistik guru dan pegawai, akan tetapi secara fungsinya belum digunakan secara maksimal. Hal ini terlihat ada beberapa papan statistik yang belum diperbarui sesuai dengan kondisi terbaru. Pada beberapa sekolah, masih tertera informasi lama tentang guru maupun pegawai yang sudah tidak mengajar di sekolah tersebut.

Pada kursi dan meja kerja kepemilikannya sebesar $63,6 \%$, hal ini dapat diartikan setengah dari sekolah sampel menyediakan kursi dan meja guru di ruang guru, sedangkan beberapa sekolah hanya menyediakan di kelas. Lemari merupakan salah satu perabot yang secara fungsinya sangat membantu guru dalam menunjang kinerja dalam proses belajar mengajar. Lemari di ruang guru mencapai 65,9\% pada sekolah sampel digunakan hanya untuk guru-guru yang tidak menjadi wali kelas, misalnya guru agama dan guru olahraga. Secara keseluruhuhan ketercapaian pada ruang guru adalah $64.88 \%$. Secara lebih rinci, data disajikan pada Tabel 5.

Tabel 5 Ketercapaian Ruang Guru Jenis prasarana Persentase ketercapaian

\begin{tabular}{lc}
\hline \multicolumn{1}{c}{ Jenis prasarana } & $\begin{array}{c}\text { Persentase } \\
\text { ketercapaian }\end{array}$ \\
\hline Perabot & $38,6 \%$ \\
Kursi dan meja tamu & $59,1 \%$ \\
Papan statistik & $63,6 \%$ \\
Kursi kerja & $63,6 \%$ \\
Meja kerja & $65,9 \%$ \\
Lemari & $79,5 \%$ \\
Papan pengumuman & \\
Perlengkapan Lain & $47,7 \%$ \\
Tempat sampah & $77,3 \%$ \\
Tempat cuci tangan & $88,6 \%$ \\
Jam dinding &
\end{tabular}

Sumber: Data diolah tahun 2014 Instrumen Ketercapaian Standar Nasional Pendidikan Tahun 2012

\section{Ruang Usaha Kesehatan Sekolah (UKS)}

Ruang UKS adalah ruang untuk penanganan dini peserta didik yang mengalami gangguan kesehatan di sekolah. Untuk menunjang secara maksimal ruang UKS perlu dilengkapi dengan beberapa perabot dan perlengkapan lainnya. Jenis perabot terdiri dari lemari, kursi, meja, tempat tidur. Jenis peralatan lainnya terdiri atas catatan kesehatan peserta didik, tandu, jam 
dinding, tensimeter, thermometer badan, tempat cuci tangan, pengukur tinggi badan, selimut, tempat sampah, timbangan badan, dan perlengkapan P3K.

Selain berfungsi untuk menanggulangi masalah kesehatan di sekolah, UKS juga berfungsi untuk melatih siswa agar sadar akan pentingnya kesehatan. Dalam ruang UKS biasanya terdapat banyak fasilitas penunjang lain dengan tujuan agar pelajar dapat belajar mengenai kesehatan. Hal ini dikarenakan pentingnya pendidikan kesehatan agar siswa dapat mengetahui hal-hal yang berkaitan dengan kesehatan dan pentingnya menjaga kesehatan dan kebersihan. Untuk tingkat ketercapaian dari kepemilikan pada tingkat perabot sudah diatas $50 \%$. Hal ini dapat diartikan bahwa hampir seluruh sekolah menyediakan empat jenis perabot yang sesuai dengan standar yang telah ditetapkan.

Perabot UKS sangat penting ada di dalam UKS-karena sangat berguna seperti tempat tidur dan kasur yang berfungsi untuk tempat tidur jika ada pelajar mengalami gangguan kesehatan. Dengan tidur di tempat yang memiliki kasur dan ranjang yang nyaman, pelajar yang mengalami masalah kesehatan tersebut bisa istirahat dengan nyaman. Meja dan kursi berfungsi untuk tempat duduk jika ada banyak pasien di UKS. Jika pasien itu banyak maka sebagian pasien dapat duduk di kursi tersebut. Adapun lemari berfungsi untuk menyimpan perlengkapan dan obat-obatan UKS.

Pada jenis perlengkapan lain- dari segi capaiannya dapat dikatakan rendah. Catatan kesehatan peserta didik yang ditemukan di beberapa sekolah sampel bentuknya bervariasi. Ada beberapa sekolah menggabungkan dengan buku bimbinganm dan konseling (BK). Persentase ketercapaian rendah dikarenakan tidak semua siswa memiliki buku/catatan kesehatan peserta didik (27,3\%). Terkait dengan hal tersebut, beberapa alasan yang dikemukakan oleh kepala sekolah/pengurus UKS adalah kurangnya pemanfaatan UKS secara maksimal, sehingga UKS hanya digunakan bila ada siswa yang sakit.
Untuk pelibatan pada kegiatan rutin seperti pengecekan kesehatan siswa secara berkala belum dilaksanakan. Pencatatan kesehatan siswa hanya terbatas pada siswa yang pernah sakit dan mengunjungi UKS. Untuk tandu $(22,7 \%)$ dan jam dinding $(27,3 \%)$, ketercapaiannya rendah dikarenakan sekolah tidak memiliki kedua perlengkapan tersebut. Untuk tandu, hampir seluruh sekolah sampel tidak memiliki dikarenakan tandu tidak pernah digunakan, meskipun ada sudah tidak layak pakai. Hal yang sama pada kurangnya ketercapaian kepemilikan seperti tensimeter, thermometer, tempat cuci tangan, pengukur badan dikarenakan kepemilikannya rendah bahkan beberapa sekolah tidak memiliki atau alat tersebut tidak dapat digunakan dikarenakan rusak berat. Dapat disimpulkan dari perolehan data pada kepemilikan perabot dan perlengkapan lain, ketercapaian pada ruang UKS adalah 49.09\%. Secara rinci data ketercapaian ruang UKS dapat dicermati pada Tabel 6

Tabel 6 Ketercapaian Ruang UKS

\begin{tabular}{lc}
\hline \multicolumn{1}{c}{ Jenis prasarana uks } & $\begin{array}{c}\text { Persentase } \\
\text { ketercapaia } \\
\mathrm{n}\end{array}$ \\
\hline Perabot & $52,3 \%$ \\
Lemari & $56,8 \%$ \\
Kursi & $63,6 \%$ \\
Meja & $72,7 \%$ \\
Tempat tidur & \\
Perlengkapan Lain & $27,3 \%$ \\
Catatan kesehatan peserta didik & $22,7 \%$ \\
Tandu & $27,3 \%$ \\
Jam dinding & $34,1 \%$ \\
Tensimeter & $43,2 \%$ \\
Termometer badan & $43,2 \%$ \\
Tempat cuci tangan & $45,5 \%$ \\
Pengukur tinggi badan & $59,1 \%$ \\
Selimut & $59,1 \%$ \\
Tempat sampah & $63,6 \%$ \\
Timbangan badan & $65,9 \%$ \\
\hline Perlengkapan P3K &
\end{tabular}

Sumber: Data diolah tahun 2014Instrumen Ketercapaian Standar Nasional Pendidikan tahun 2012 


\section{Jamban (Toilet)}

Salah satu sarana yang sangat penting keberadaannya di sekolah adalah jamban. Fungsi jamban adalah sebagai tempat buang air besar dan/atau kecil. Jamban harus memenuhi standar luasnya, ditunjang oleh ketersediaan air bersih, serta dilengkapi oleh sarana penunjang di dalamnya. Adapun sarana yang harus tersedia di dalam jamban adalah gantungan pakaian, tempat sampah, tempat air, gayung, dan kloset jongkok.

Untuk jamban, pada sekolah dasar dibagi menjadi dua, yaitu jamban untuk kepala sekolah/ guru dan jamban untuk siswa.Untuk lokasinya ada yang bersebelazhan antara jamban kepalasekolah/guru dan siswa, tetapi ada yang berjauhan. Umumnya, untuk tingkat kebersihan, jamban kepala sekolah/guru lebih bersih dibandingkan dengan jamban siswa. Jamban kepala sekolah/guru lebih sering dikunci dibandingkan dengan jamban siswa yang siapapun dapat mengakses dengan mudah.

Pada perabot yang ada di jamban, beberapa sekolah tidak memiliki gantungan pakaian dan tempat sampah, sedangkan secara fungsinya kedua perabot tersebut sangat penting dalam menunjang aktivitas di jamban. Hal ini membuat ketercapaian pada dua perabot tersebut rendah (20,5\% dan 34,1\%).Di beberapa sekolah sampel lainnya membuat gantungan baju dengan ala kadarnya dengan menancapkan paku ke dinding jamban dan diberikan pengait dimana secara fungsinya adalah sebagai gantungan pakaian, sedangkan ketersediaan tempat air, gayung, dan kloset jongkok cukup tinggi $(70,5 \%, 77,3 \%$, dan $81,8 \%)$. Dari analisis data yang diperoleh ketercapaian kepemilikan jamban belum mencapai sesuai dengan standar yang telah ditentukan, yaitu 50.63\%. Data lebih lengkap terlampir dalam Tabel 7.
Tabel 7 Ketercapaian Ruang Jamban (Toilet)

\begin{tabular}{lc}
\hline \multicolumn{1}{c}{ Jenis prasarana } & $\begin{array}{c}\text { Persentase } \\
\text { ketercapaian }\end{array}$ \\
\hline Perabot & \\
Gantungan pakaian & $20,5 \%$ \\
Tempat sampah & $34,1 \%$ \\
Tempat air & $70,5 \%$ \\
Gayung & $77,3 \%$ \\
Kloset jongkok & $81,8 \%$ \\
\hline
\end{tabular}

Sumber: Data diolah tahun 2014Instrumen Ketercpaian Standar Nasional Pendidikan tahun 2012

\section{Tempat Bermain dan Berolahraga}

Secara fungsi, tempat bermain dan berolahraga adalah sebagai area bermain, berolahraga pendidikan jasmani, upacara bendera, dan tempat kegiatan pembelajaran di luar kelas. Beberapa kriteria sebagai tempat bermain dan berolahraga di sekolah adalah 1 ) tempat tersebut ditanami oleh pohon penghijauan; 2) tidak dipakai untuk lahan parkir; 3) tempat bermain ditempatkan yang paling sedikit mengganggu proses pembelajaran di kelas; 4) memiliki beberapa alat perlengkapan untuk menunjang kegiatan bermain dan berolahraga.

Umumnya tempat bermain dan berolahraga berada di depan mengelilingi ruang kelas. Namun, ada juga pada beberapa sekolah sampel tempat bermain dan berolahraga berada disamping lingkungan deretan ruang kelas. Beberapa sekolah sampel menjadikan tempat bermain sebagai tempat olahraga, seperti lapangan bola basket, lapangan bulu tangkis, dan lapangan badminton. Selain dari tempat bermain juga sering digunakan sebagai aula terbuka untuk siswa dalam melakukan bermacam kegiatan seperti kegiatan pramuka, kegiatan kesenian dan budaya. Tempat bermain dan berolahraga didukung oleh beberapa alat perabot dan peralatan olahraga guna menunjang fungsi kegunaan ruang tersebut. Menurut standar sarana prasarnana, perabot tempat bermain dan olahraga terdiri dari tiang bendera dan bendera. Untuk peralatan olahraga terdiri dari peralatan keterampilan, peralatan senam, 
peralatan seni budaya, peralatan bola basket, peralatan atletik, peralatan sepak bola, dan peralatan bola voli, sedangkan perlengkapan lain terdiri dari pengeras suara dan tape recorder. Untuk tingkat ketercapaian pada kepemilikan peralatan olahraga masih sangat rendah, yaitu dibawah $50 \%$ kecuali peralatan bola voli $(75,0 \%)$. Rendahnya tingkat ketercapaian kepemilikan tersebut dikarenakan kurang lengkapnya peralatan yang dimiliki sekolah. Misalnya, pada peralatan keterampilan, beberapa sekolah tidak memiliki peralatan tersebut. Dalam keterangan pada standar sarana prasarana, peralatan keterampilan adalah peralatan yang dimiliki sekolah yang disesuaikan dengan potensi di sekolah tersebut. Beberapa sekolah sampel belum menerapkan secara maksimal tentang informasi tersebut. Untuk peralatan senam, seni budaya, bola basket ketercapaian kepemilikannya pun rendah masih dibawah 50\% akibat ketidaklengkapan peralatan yang dimiliki. Pada beberapa sekolah sampel, hanya ada yang memiliki bolanya tetapi tidak memiliki ring basket/net bola voli. Bola yang dimiliki juga tidak sebanding dengan jumlah siswa.Kondisi bola bervariasi, hanya sedikit yang layak pakai. Penyimpanan peralatan tersebut sebagian sekolah di gudang sekolah, ada pula yang menyimpannya di lemari guru olahraga dikarenakan sekolah tidak memiliki gudang.Pada perabot tiang bendera dan bendera ketercapaian sudah tinggi masing-masing sebesar $93,2 \%$ sekolah memilikinya. Hal yang sama dengan perlengkapan lain yang dimiliki oleh sekolah sampel, yaitu pengeras suara dantape recorder. Minimal masing-masing sekolah sampel memiliki kedua benda tersebut sebanyak satu buah. Secara fungsinya disekolah, pengeras suara dan tape recorder sangat menunjang sekolah dalam melakukan kegiatan proses belajar mengajar. Dari rincian data yang telah dipaparkan, dapat diasumsikan ketercapaian pada tempat bermain dan berolahraga adalah 62.74\%. Data secara lengkap disajikan pada Tabel 8.
Tabel 8 Ketercapaian Tempat Bermain dan Olahraga

\begin{tabular}{lc}
\hline \multicolumn{1}{c}{ Jenis prasarana } & $\begin{array}{c}\text { Persentase } \\
\text { ketercapaian }\end{array}$ \\
\hline Perabot & \\
Tiang bendera & $93,2 \%$ \\
Bendera & $93,2 \%$ \\
Peralatan olahraga & \\
Peralatan keterampilan & $34,1 \%$ \\
Peralatan senam & $36,4 \%$ \\
Peralatan seni budaya & $36,4 \%$ \\
Peralatan bola basket & $47,7 \%$ \\
Peralatan atletik & $54,5 \%$ \\
Peralatan sepak bola & $62,8 \%$ \\
Peralatan bola voli & $75,0 \%$ \\
Perlengkapan Lain & \\
Pengeras suara & $81,8 \%$ \\
Tape recorder & $75,0 \%$ \\
\hline
\end{tabular}

Sumber: Data diolah tahun 2014Instrumen Ketercpaian Standar Nasional Pendidikan tahun 2012

Dari uraian pada tiap prasarana, tingkat ketercapaian pada tiap ruang bervariasi. Capaian kepemilikan prasarana dapat mencerminkan tingkat capaian yang secara keseluruhan belum diasumsikan memilki ketercapaian secara merata pada tiap ruang yang ada di sekolah. Ketujuh prasarana yang terdiri dari ruang kelas, ruang pimpinan, ruang perpustakaan, ruang guru, ruang unit kesehatan sekolah (UKS), jamban, tempat bermain dan berolahraga. Dari ke-tujuh ruang tersebut dapat diurutkan tingkat ketercapaian dari perolehan rata-rata kepemiikan. Tingkatan yang tertinggi yaitu capaian pada ruang pimpinan $79,84 \%$. Capaian pada ruang kepala sekolah dapat diartikan dapat menunjang tugas pimpinan sebagai edukator, manajer, administrator, supervisor, pemimpin/Leader, inovator, dan motivator, dimana seluruh tugas tersebut dilaksanakan di ruang pimpinan. Untuk tingkatan tertinggi berikutnya adalah capaian ruang guru yaitu $64.88 \%$. Hal ini dapat diartikan bahwa tingkat ketercapaian pada ruang guru sudah dapat membantu dalam menunjang kegiatan guru sesudah melakukan proses belajar 
menangajar di kelas. Urutan ketiga, yaitu ruang kelas. Tingkat capaian pada ruang kelas adalah $62.83 \%$, hal ini dapat menunjang proses belajar mengajar secara lancar untuk guru dan siswa meski belum maksimal. Capaian keseluruhan pada ruang bermain merupakan capaian urutan empat yaitu $62.74 \%$. Dengan capaian tersebut kesusuaian tujuan dari ruang tersbut yaitu kegiatan aktivitas siswa dan guru dalam bermain dan berolahraga dapat dilaksanakan. Tiga ruang berikut ini merupakan ruang yang capaian rendah dibawa $50 \%$, yakni ruang perpustakaan $(56.92 \%)$, jamban $(50,63 \%)$, dan ruang UKS (49.09\%). Rendahnya ketercapaian pada ketiga ruang tersebut dikarenakan pada hal yang sama yaitu kurangnya jumlah ketersediaan pada perabot, perlengkapan lain pada ruangan tersebut. Selain dari itu kondisi perabot dan perlengkapan yg dimiliki banyak yang kondisinya sudah rusak berat seingga sudah tidak dapat digunakan. Rendahnya pencapaian pada ruang tersebut tentunya akan menghambat fungsi dari ketiga ruang tersebut.

\section{SIMPULAN DAN SARAN}

\section{Simpulan}

Berdasarkan survei yang dilakukan pada sekolahsekolah sampel, diperoleh data bahwa secara umum tingkat ketercapaian standar prasarana untuk SD rata-rata 60,94\%. Tingkat ketercapaian ini nampaknya masih rendah disebabkan oleh masih minimnya prasarana yang dimiliki oleh sekolah. Di samping itu, walaupun beberapa sekolah sudah memiliki prasarana, kondisi kualitas prasarananya banyak mengalami rusak berat sehingga sudah tidak layak lagi untuk digunakan. Jenis-jenis prasarana yang persentase ketercapaiannya di atas rata-rata meliputi ruang pimpinan, ruang guru, ruang kelas, ruang bermain dan berolahraga. Prasarana yang ketercapaiannya masih kurang dari rata-rata adalah perpustakaan, jamban, dan ruang UKS.

\section{Saran}

Pendataan awal tentang kebutuhan prasarana sekolah sangat diperlukan untuk dapat pemerintah daerah memetakan bantuan prasarana sesuai dengan kebutuhan sekolah. Dalam pelibatan pemenuhan ketercapaian prasarana yang ada perlunya pemerintah pusat dan pemerintah daerah bersinergi guna memenuhi kebutuhan sarana dan prasarana sekolah selain peran kepala sekolah sendiri. Selain itu, perlunya pelatihan kepada sekolahsekolah yang menerima bantuan prasarana untuk dapat menggunakan secara maksimal guna menunjang proses belajar mengajar. Untuk tingkat sekolah, agar dapat ditunjuk tim penanggung jawab sarana prasarana yang tugasnya tidak hanya sebagai bagian dari struktur organisasi, melainkan juga untuk bertanggung jawab dalam menginventarisasikan dan perawatan pada prasarana sekolah. Kontribusi yang tinggi dari masyarakat dan orangtua dalam partisipasi pemenuhan sarana prasarana sebaiknya tidak perlu dilarang.

\section{UCAPAN TERIMAKASIH}

Ucapan terimakasih penulis sampaikan kepada peneliti Subijanto atas arahan, bimbingan, dan masukan dalam penulisan artikel ini.

\section{PUSTAKA ACUAN}

Basuki, T. 2010. Pengaruh Pemanfaatan Sarana dan Prasarana terhadap Motivasi Belajar Siswa di Sekolah Menengah Pertama Islam Durenan Tulungggagung. Skripsi. Tulungagung: Fakultas Tarbiyah Sekolah Tinggi Agama Islam Negeri Tulungagung.

Dharmastuti, H. 2014. Manajemen Sarana dan Prasarana dalam Upaya Peningkatan Kualitas Pembelajaran pada Jurusan Teknik Komputer dan Informatika di SMK Negeri 2 Surabaya. Jurnal Inspirasi Manajemen Pendidikan, 3 (3), hlm. 9 
Dimyati dan Mudjiono. 2006. Belajar dan Pembelajaran. Jakarta: Rineka Cipta.

Herlino, A. 2013. Asesmen Kebutuhan Organisasi Persekolahan: tinjauan perilaku organisasi menuju comprehensive multilevel planning. Jakarta: Gramedia Pustaka Utama

https://uses.wordpress.com/kualitas-pendidikan-di-indonesia/, diakses 12 November 2014.

http://unic-jakarta.org/2014/07/25/laporan-pembangunan-manusia-2014-peluncuran-global-implikasi-lokal/ diakses 14 Desember 2014.

Jannah, M. 2010. Optimalisasi Manajemen Sarana dan Prasarana dalam Meningkatkan Mutu Pembelajaran di SMP Nasima Semarang. Skripsi. Semarang: Institut Agama Islam Negeri Walisongo Fakultas Tarbiyah.

Kamus Besar Bahasa Indonesia Daring. 2008. http://badanbahasa.kemdikbud.go.id/kbbi/

Kompas.com. 2 Maret 2011.http://edukasi.kompas.com/read/2011/03/02/18555569/ indeks.pendidikan.indonesia.menurun, diakase Desember 2014.

Kompas.com. 9 Maret 2012. http://edukasi.kompas.com/read/2012/03/09/08310552/ Dari.100.Nilai.Rata-rata.Uji.Kompetensi.Guru.Hanya.35, diakses 9 Desember 2014.

Kementerian Pendikdikan dan Kebudayaan. 2012. Rembug Nasional Kementerian Pendidikan dan Kebudayaan Tahun 2012. Jakarta: Kementerian Pendidikan dan Kebudayaan.

Peraturan Menteri Pendidikan Nasional Republik Indonesia Nomor 24 Tahun 2007 tentang Standar Sarana dan Prasarana untuk Sekolah Dasar/Madrasah Ibtidaiyah (SD/MI), Sekolah Menengah Pertama/Madrasah Tsanawiyah (SMP/MTs), dan Sekolah Menengah Atas/ Madrasah Aliyah (SMA/MA).

Raharjo, S.B. 2012. Evaluasi Tren Kualitas Pendidikan di Indonesia. Jurnal Penelitian dan Evaluasi Pendidikan, 16(2), hlm. 511.

Raharjo, S.B. 2014. Kontribusi Delapan Standar Nasional Pendidikan terhadap Pencapaian Prestasi Belajar. Jurnal Pendidikan dan Kebudayaan, 20(4), hlm. 470-482.

Santoso, J. 2011. Hubungan Manajemen Sarana dan Prasarana Sekolah, Dampak Sertifikasi Guru, Iklim Sekolah, dan Motivasi Berprestasi Guru dengan Kinerja Guru pada SMK Negeri di Malang Raya.Disertasi. Malang: Program Pasca Sarjana Universitas Negeri Malang.

Subijanto \& Siswo Wiratno. 2012. Analisis Kinerja Badan Akreditasi Nasional Sekolah/Madrasah. Jurnal Pendidikan dan Kebudayaan, 18 (3), hlm. 310-318.

Sugiyono. 2011. Metode Penelitian Pendidikan. Bandung: Alfabeta

Triwiyanto, T. 2013.Standar Nasional Pendidikan sebagai Indikator Mutu Layanan Manajemen Sekolah. Jurnal Ilmu Pendidikan, 19(2), 2013, hlm. 161.

UNESCO. 2011. Education For All (EFA) Global Monitoring Report, http://unesdoc. unesco.org/ images/0019/001907/190743e.pdf. Diakses pada tanggal 15 Oktober 2012.

UNESCO.2015. Education For All (EFA) Global Monitoring Report. http://unesdoc.unesco.org/ images/0023/002322/232205e.pdf. Diakses 30 Maret 2016.hlm.232. 
Relisa, Kajian Prasarana Pendidikan Sekolah Dasar Sebagai Salah Satu Indikator Pencapaian Standar Nasional Pendidikan 